\title{
WYOMING GROUND-WATER QUALITY
}

By Karen L. Mora, L. Rodney Larson, and Samuel J. Rucker IV

U.S. Geological Survey Open-File Report 87-0763 
DEPARTMENT OF THE INTERIOR

DONALD PAUL HODEL, Secretary

U.S. GEOLOGICAL SURVEY

Dallas L. Peck, Director

For additional information:

Chief Hydrologist

U.S. Geological Survey

407 National Center

Reston, VA 22092
For sale by:

U.S. Geological Survey

Books and Open-File Reports Section Federal Center

Box 25425

Denver, Colorado 80225

Use of trade names in this report is for descriptive purposes only and does not constitute endorsement by the U.S. Geological Survey 


\section{FOREWORD}

This report contains summary information on ground-water quality in one of the $\mathbf{5 0}$ States, Puerto Rico, the Virgin Islands, or the Trust Territories of the Pacific Islands, Saipan, Guam, and American Samoa. The material is extracted from the manuscript of the 1986 National Water Summary, and with the exception of the illustrations, which will be reproduced in multi-color in the 1986 National Water Summary, the format and content of this report is identical to the State ground-water-quality descriptions to be published in the 1986 National Water Summary. Release of this information before formal publication in the 1986 National Water Summary permits the earliest access by the public. 
Contents

Ground-Water Quality $\ldots \ldots \ldots \ldots \ldots \ldots \ldots \ldots \ldots \ldots \ldots \ldots \ldots \ldots$

Water-Quality in Principal Aquifers $\ldots \ldots \ldots \ldots \ldots \ldots \ldots \ldots \ldots \ldots \ldots$

Background Water Quality $\ldots \ldots \ldots \ldots \ldots \ldots \ldots \ldots \ldots \ldots \ldots \ldots \ldots$

Alluvial Aquifer $\ldots \ldots \ldots \ldots \ldots \ldots \ldots \ldots \ldots \ldots \ldots \ldots \ldots \ldots \ldots \ldots \ldots \ldots \ldots$

High Plains and Equivalent Aquifers $\ldots \ldots \ldots \ldots \ldots \ldots \ldots \ldots$

Structural Basin Aquifer ..................... 2

Carbonate and Sandstone Aquifer ................. 3

Effects of Land Use on Water Quality ................... 3

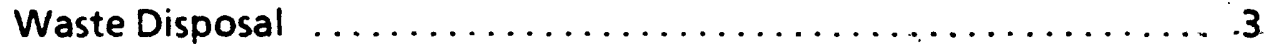

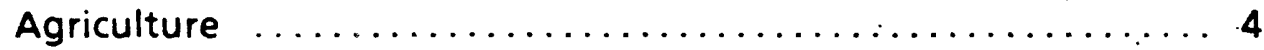

Mineral Extraction and Processing $\ldots \ldots \ldots \ldots \ldots \ldots \ldots \ldots$

Urbanization .............................. 4

Potential for Water-Quality Changes $\ldots \ldots \ldots \ldots \ldots \ldots \ldots \ldots \ldots$

Ground-Water-Quality Management ..................... 5

Selected References $\ldots . \ldots \ldots \ldots \ldots \ldots \ldots \ldots \ldots \ldots \ldots \ldots \ldots \ldots \ldots \ldots$

Illustrations

Figure 1.--Selected geographic feature and 1985 population distribution in Wyoming.

Figure 2.--Principal aquifers and related water-quality data in Wyoming.

Figure 3.--Selected waste sites and ground-water quality information in Wyoming. 


\section{WYOMING Ground-Water Quality}

Ground water that is suitable for most uses has contributed to the development of Wyoming. Wells and springs provide drinking water for 65 percent of the population (fig. 1) and are the principal source of water for livestock (Wyoming Department of Environmental Quality, 1986a, p. 296). In many parts of the State, ground water is the only source of water because surface water is absent, unreliable, or already appropriated. Most ground-water withdrawals in Wyoming are used for irrigation (69 percent) and industry (24 percent), which include power generation, secondary and tertiary oil recovery, and uranium mining and processing.

Ground-water quality (fig. 2) differs greatly between and within aquifers throughout Wyoming. Dissolved-solids concentrations commonly are large. Where dissolved-solids concentrations are large. usually the concentrations of sulfate or chloride generally are large also. Naturally occurring. but large concentrations of fluoride, sclenium. iron. manganese, radionuclides, and hardness are also common (fig. 3).

Despite the small population density (fig. 1), ground water has been contaminated in localized areas of Wyoming. The most common contaminants are gasoline and diesel fuel leaking from underground storage tanks, and nitrate from septic-tank leach fields, from applied fertilizers, and from corrals and feedlots. The potential for ground-water contamination exists from the 17,000 tons of hazardous wastes reported to be produced annually in Wyoming (Wyoming Department of Environmental Quality, 1987). These wastes include only the hazardous wastes that are regulated by the U.S. Environmental Protection Agency (EPA) under provisions of the Resource Conservation and Recovery Act (RCRA) of 1976. In addition. the U.S. Department of Defense has recommended 17 sites at 1 facility for a comprehensive survey to determine whether contamination exists.

In general. the water-quality data do not indicate widespread contamination. The data generally reflect only samples collected from wells that are not in areas of contamination and analyses that were limited to major inorganic constituents commonly found in ground water. Data for potential organic contaminants in ground water. including pesticides, are not available for most areas in the State.

\section{WATER QUALITY IN PRINCIPAL AQUIFERS}

More than 100 different aquifers are used for ground-water supplies in Wyoming (Larson, 1984, p. 12), some of which have been grouped into four principal aquifers (U.S. Geological Survey, 1985 , p. 453). From youngest to oldest, these aquifers are the alluvial aquifer, the High Plains and equivalent aquifers, the structural basin aquifer, and the carbonate and sandstone aquifer (figs. $2 A, 2 B$ ).

Ground-water quality in Wyoming is affected by both natural conditions and human activities. About 60 percent of ground-water samples collected from principal aquifers in Wyoming contain large dissolved-solids concentrations. Much of the ground water in Wyoming is naturally hard. Large nitrate concentrations are not common but are a concern locally because large concentrations are potentially lethal to infants. Large nitrate concentrations, which are mostly associated with human activities (Larson, 1984, p. 62), are most common in water from the alluvial aquifer and where the other aquifers occur at shallow depths. Large concentrations of fluoride generally are found in water from the structural basin aquifer. Large concentrations of selenium have been measured in about 2 percent of the $\mathbf{2 2 5}$ ground-water analyses in the U.S. Geological Survey's water-quality file, as of 1983 (Larson, 1984, p. 67). In addition to data in the file, Crist (1974) documented concentrations as large as $1,300 \mu \mathrm{g} / \mathrm{L}$ (micrograms per liter) in water samples from wells. in a $725-\mathrm{mi}^{2}$ (square mile) area near Casper. However. stateu'ide data are too sparse to define the location and extent of all large concentrations of selenium.

Concentrations of other toxic metals elements, such as dissolved arsenic, barium, cadmium, chromium, lead, and mercury, in ground water from the principal aquifers generally do not limit water use in Wyoming. Large iron and manganese concentrations, which are objectionable for esthetic and economic reasons. are fairly common in water that is used for domestic purposes (Larson, 1984, p. 68).

\section{BACKGROUND WATER QUALITY}

The concentrations of dissolved solids, hardness, nitrate. fluoride, and selenium in water from the four principal aquifers are graphically summarized in figure $2 C$ from data stored in the U.S. Geological Survey's National Water Data Storage and Retrieval System (WATSTORE). The summary is based on analyses of water samples collected from 1960 to 1985 from the principal aquifers in Wyoming. The data reflect the general water quality of the aquifers being used for livestock or domestic supplies.

The percentiles used in figure $2 C$ are compared to national standards that specify the maximum concentration or level of a contaminant in drinking-water supply as established by the U.S. Environmental Protection Agency (1986a,b). The primary maximum contaminant standards are health related and are legally enforceable. The secondary maximum contaminant standards apply to esthe $\mathrm{k}$ qualities and are recommended guidelines. The maximum concentrations permitted by primary drinking-water standards are as follows: nitrate (as nitrogen), $10 \mathrm{mg} / \mathrm{L}$ (milligrams per liter): fluoride, $4 \mathrm{mg} / \mathrm{L}$; and selenium, $10 \mu \mathrm{g} / \mathrm{L}$. The maximum concentrations recommended by secondary drinking-water standards are as follows: dissolved solids, $500 \mathrm{mg} / \mathrm{L}$; fluoride, $2 \mathrm{mg} / \mathrm{L}$.

In applying these water-quality standards, the assumed use of the aquifers is for drinking. However, an evaluation of $u$ ates quality for other uses would require that other criteria be applied Generally, if the water is well suited for drinking, it also is well suited for most other uses.

Areas of naturally impaired water quality have been delineated by the Wyoming Department of Environmental Quality (WDEQ) (fig. 3B) using data in their files, files of the Wyoming State Engineer, and a report (Wyoming Water Resources Research Institute, 1981) prepared for the EPA. Naturally occurring constituents that cause the water to be impaired include fluoride, selenium. and radionuclides. Most areas (fig. 3B) were delineated on the basis of fluoride concentrations exceeding the secondary drinking-water standard of $2 \mathrm{mg} / \mathrm{L}$. Concentrations of selenium larger than $10 \mu \mathrm{g} / \mathrm{L}$ were measured in two areas. Three areas were delineated on the basis of levels of radionuclides larger than $5 \mathrm{pCi} / \mathrm{L}$ (picocuries per liter) for radium 226 plus radium 228, larger than $15 \mathrm{pCi} / \mathrm{L}$ for gross alpha activity, larger than $8 \mathrm{pCi} / \mathrm{L}$ for strontium 90 , or larger than $20,000 \mathrm{pCi} / \mathrm{L}$ for tritium. Two areas were delineated on the basis of selenium concentrations or radionuclide levels in addition to fluoride concentrations.

Water may be available from more than a single aquifer in some areas, and the data used for figure $3 B$ do not represent any one aquifer. Therefore, water that is suitable for domestic use may be available within an area shown as naturally impaired. The areas of naturally impaired water quality (fig. $3 B$ ) generally are based on a few scattered wells and also represent several different aquifers. 


\section{Alluvial Aquifer}

The alluvial aquifer, comprised of gravel, sand. silt, and clay, is located in the valleys and terraces adjacent to most large streams in Wyoming (fig. $2 A$ ). The alluvial aquifer generally is less than 50 feet thick; however, thicknesses may exceed 200 feet in the Bear River and Snake River drainage basins. Only extensive areas of the alluvial aquifer with potential yields of more than $100 \mathrm{gal} / \mathrm{min}$ (gallons per minute) are mapped in figure $2 A$. Many small areas of the alluvial aquifer with lesser potential yields are important locally.

Concentrations of dissolved solids and other variables in water samples from the alluvial aquifer (aquifer 1) are graphically summarized in figure $2 C$. Ten percent of the analyses of water samples collected from the alluvial aquifer had dissolved-solids concentrations of $192 \mathrm{mg} / \mathrm{L}$ or less; 25 percent were $330 \mathrm{mg} / \mathrm{L}$ or less. The median concentration was $480 \mathrm{mg} / \mathrm{L}$. Seventy-five percent of the concentrations were $760 \mathrm{mg} / \mathrm{L}$ or less, and 90 percent were 1.580 $\mathrm{mg} / \mathrm{L}$ or less. Slightly more than 50 percent of the dissolved-solids concentrations did not exceed the secondary drinking-water standard of $500 \mathrm{mg} / \mathrm{L}$

Most water from the alluvial aquifer was very hard. The median hardness concentration was $280 \mathrm{mg} / \mathrm{L}$ (as calcium carbonate)the largest median concentration of the four principal aquifers.

Nitrate concentrations in 90 percent of the samples did not exceed the drinking-water standard of $10 \mathrm{mg} / \mathrm{L}$ (as nitrogen); most of the remaining samples greatly exceeded the limit. The maximum concentration was $70 \mathrm{mg} / \mathrm{L}$ (as nitrogen).

Although concentrations of fluoride in about 90 percent of the water samples from the alluvial aquifer did not exceed the secondary drinking-water standard of $2 \mathrm{mg} / \mathrm{L}$ (fig. $2 C$ ), concentrations in 9 percent of the samples exceeded the primary drinkingwater standard of $4 \mathrm{mg} / \mathrm{L}$. Nearly all large fluoride concentrations were measured in water samples collected from alluvial aquifers in Yellowstone National Park. (Large fluoride concentrations commonly are associated with volcanism.) Concentrations of fluoride ranged from 0.1 to $9.1 \mathrm{mg} / \mathrm{L}$. and the median concentration was $0.7 \mathrm{mg} / \mathrm{L}$

Selenium concentrations exceeded the $10-\mu \mathrm{g} / \mathrm{L}$ standard in 36 of 83 samples collected from the alluvial aquifer in a $725-\mathrm{mi}^{2}$ irrigation project near Casper (Crist, 1974); the largest concentration was $1,300 \mu \mathrm{g} / \mathrm{L}$. These samples were collected from an area where selenium is known to be a problem. They are not representative of selenium concentrations found in ground-water samples collected from the alluvial aquifer in the remainder of the State.

Other than in the area near Casper, only three ground-water samples collected from the alluvial aquifer and analyzed for selenium are contained in the data base; therefore, selenium data for the alluvial aquifer are not included in figure $2 C$. All three concentrations were at or below the $1-\mu \mathrm{g} / \mathrm{L}$ detection limit.

\section{High Plains and Equivalent Aquifers}

Large yields of water from wells and excellent water quality make this aquifer a valuable water resource. Wells in the unconsolidated to consolidated gravel, sand, and silt of the High Plains and equivalent aquifers provide water that is well suited and most commonly used for irrigation, public, livestock, and domestic supplies.

Water samples from the High Plains and equivalent aquifers had the smallest median dissolved-solids concentration $(260 \mathrm{mg} / \mathrm{L})$ of the four principal aquifers (fig. 2C). Concentrations of dissolved solids in about 80 percent of the water samples from the High Plains aquifer in southeastern Wyoming and equivalent aquifers in southern Carbon County were smaller than the recommended drinking-water standard of $500 \mathrm{mg} / \mathrm{L}$. However, dissolved-solids concentrations were smaller than the recommended drinking-water standard in 60 percent of the water samples from an equivalent aquifer in southern Carbon County (Larson, 1984, p. 23).

Most water samples from the High Plains and equivalent aquifers were moderately hard to hard. The median hardness concentration was $160 \mathrm{mg} / \mathrm{L}$ (as calcium carbonate).

Nitrate concentrations in $\mathbf{2}$ of $\mathbf{8 7}$ samples of water from the High Plains and equivalent aquifers exceeded the drinking-water standard of $10 \mathrm{mg} / \mathrm{L}$ (as nitrogen). The maximum concentration of nitrate was $176 \mathrm{mg} / \mathrm{L}$ (as nitrogen)-the largest in water samples from the four principal aquifers. Although nitrate concentrations generally are small in the water samples from the High Plains and equivalent aquifers, concentrations are locally large around communities.

Fluoride concentrations in water samples from the High Plains and equivalent aquifers generally were less than the secondary drinking-water standard of $2 \mathrm{mg} / \mathrm{L}$. One of the 103 samples, with a concentration of $5 \mathrm{mg} / \mathrm{L}$, exceeded the primary drinkingwater standard of $4 \mathrm{mg} / \mathrm{L}$.

Three samples from the High Plains and equivalent aquifers were measured for selenium. The concentrations $(1,2$, and $5 \mu \mathrm{g} / \mathrm{L}$ ) did not exceed the primary drinking-water standard $(10 \mu \mathrm{g} / \mathrm{L})$.

\section{Structura! Basin Aquifer}

The structural basin aquifer, found in most structural basins in Wyoming, is the most widespread and most extensively used aquifer in terms of number of wells. This aquifer is the only available source of water in many localities and generally is used by municipalities and rural areas for domestic and livestock supplies Thickness of the lenticular beds of sandstone, coal, and shale of this aquifer may exceed 5,000 feet. Yields of water to wells generally are less than $50 \mathrm{gal} / \mathrm{min}$. Much of the aquifer is confined. and flowing wells are common.

Although the water quality in the structural basin aquifer generally is well suited for livestock watering, the water commonly is less than desirable for a domestic drinking-water supply. Dissolved-solids concentrations commonly exceed the recommended limit of $500 \mathrm{mg} / \mathrm{L}$. The median dissolved-solids concentration for water samples from the structural basin aquifer was $1,100 \mathrm{mg} / \mathrm{L}-$ the largest median of the four principal aquifers. Seventeen percent of the 529 samples did not exceed the recommended limit of $500 \mathrm{mg} / \mathrm{L}$. Ninety-five percent of the samples contained $5,000 \mathrm{mg} / \mathrm{L}$ or less, which is suitable for watering livestock.

A median hardness concentration of $160 \mathrm{mg} / \mathrm{L}$ (as calcium carbonate) for water samples from the structural basin aquifer is the same as the median concentration for water samplès from the High Plains and equivalent aquifers. The structural basin aquifer generally yields water that has been naturally softened by the exchange of calcium and magnesium ions for sodium ions; therefore. water in about 30 percent of the water samples was soft.

Nitrate concentrations in most of the water samples from the structural basin aquifer were at or less than the detection limit $(0.1$ $\mathrm{mg} / \mathrm{L}$, nitrate as nitrogen). Nitrate concentrations exceeded the drinking-water standard in 10 of 335 amples; the maximum concentration was $86 \mathrm{mg} / \mathrm{L}$ (as nitrogen).

The median concentration of fluoride in $\mathbf{5 3 3}$ water samples from the structural basin aquifer was $0.6 \mathrm{mg} / \mathrm{L}$ - the second largest of the four aquifers. The concentration for the 90th percentile (3.6 $\mathrm{mg} / \mathrm{L}$ ) was the largest of the four principal aquifers. Seventeen percent of the samples had concentrations that exceeded the secondary drinking-water standard of $2 \mathrm{mg} / \mathrm{L}$, and 8 percent exceeded the primary drinking-water standard of $4 \mathrm{mg} / \mathrm{L}$. The maximum fluoride concentration was $13 \mathrm{mg} / \mathrm{L}$.

Selenium concentrations in 93 of 103 water samples collected from the structural basin aquifer were at or below the detection limit of $1 \mu \mathrm{g} / \mathrm{L}$. Concentrations in 5 percent of the samples exceeded 
the primary drinking-water standard of $10 \mu \mathrm{g} / \mathrm{L}$; the maximum concentration was $80 \mu \mathrm{g} / \mathrm{L}$.

\section{Carbonate and Sandstone Aquifer}

The carbonate and sandstone aquifer is recharged where exposed at the edges of the basins in largely uninhabited, mountainous terrain. This aquifer becomes progressively more deeply buried toward the center of the basins. The thickness of limestone. dolomite, and sandstone that compose this aquifer may be several thousands of feet. Large secondary permeability (solution cavities, joints, and fractures) characterizes this aquifer; therefore. large yields of water to wells are possible. Yields of 100 to $700 \mathrm{gal} / \mathrm{min}$ are common. but one well near Worland (Washakie County) has reportedly flowed at $14.000 \mathrm{gal} / \mathrm{min}$.

Although the water quality is excellent at or near the edges of the basins, fewer wells are completed in this aquifer than in any of the other three aquifers. Because of the great depth to the aquifer except near the edges of the basins, the drilling and completion of a well are too expensive for many potential users. Abundant streamflou and springs in the largely uninhabited recharge areas provide water for livestock and wildlife. Although the dissolvedsolids concer' rations were small in samples from wells and springs near the recharge areas, concentrations were larger in samples from wells tow ard the center of the basins. Therefore. location is an important facti; in describing the water quality of this aquifer.

The median dissolved-solids concentration in samples collected from uclls and springs in the carbonate and sandstone aquifer was $280 \mathrm{mg} / \mathrm{L}$. only slightly larger than the median concentration for water samples from the High Plains and equivalent aquifers The maximum dissolved-solids concentration in any sample $u$ ds $9,400 \mathrm{mg} / \mathrm{L}$.

W'ater from this aquifer tends to be very hard. The median hardness concentration was $260 \mathrm{mg} / \mathrm{L}$ (as calcium carbonate).

None of the 117 samples from the carbonate and sandstonc aquifer anal zed for nitrate exceeded the drinking-water standar' of $10 \mathrm{mg} / \mathrm{L}$ (as nitrogen). The maxımum concentration was 7.5 $\mathrm{mg} / \mathrm{L}$ (as nitrogen). Common sources of nitrate contamination generally are absent in the mountainous outcrop area.

The median fluoride concentration $(0.3 \mathrm{mg} / \mathrm{L})$ in water fron; the carbonate and sandstone aquifer is the smallest of the four principal aquifers. Of the 187 water samples from the carbonate and sandstone aquifer. 15 percent exceeded the secondary drinking-water standard $(2 \mathrm{mg} / \mathrm{L})$, and 4 percent exceeded the primary drinkingwater standard $(4 \mathrm{mg} / \mathrm{L})$. The maximum concentration was 6.1 $\mathrm{mg} / \mathrm{L}$. All samples that exceeded the primary drinking-water standard for fluoride also had dissolved-solids concentrations that exceeded $2,600 \mathrm{mg} / \mathrm{L}$, which generally is unsuitable for domestic use.

None of the 27 water samples from the carbonate and sandstone aquifer analyzed for selenium had concentrations that exceeded the primary drinking-water standard of $10 \mu \mathrm{g} / \mathrm{L}$. The median concentration was the detection limit $(1 \mu \mathrm{g} / \mathrm{L})$.

\section{EFFECTS OF LAND USE ON WATER QUALITY}

Ground-water quality has changed in some areas of Wyoming because of the effects of waste disposal. agriculture, mineral extraction and processing, and urbanization. Water-quality contaminants at eight sites have been documented under the RCRA of 1980 and one site is on the National Priorities List (NPL) under the Comprehensive Environmental Response, Compensation, and Liability Act (CERCLA or Superfund) of 1980 (fig. 3A). Most severe water-quality problems have been local, and the usefulness of principal aquifers has not been impaired (Wyoming Department of Environmental Quality, 1986a). Statewide contamination of aquifers in Wyoming is not a significant problem because of distribution of the industrial development and the sparse population of about
5 persons per $\mathrm{mi}^{2}$ in 1980 (Wyoming Department of Administration and Fiscal Control, 1983).

Areas of human-induced contamination have been delineated by the WDEQ (fig. $3 B$ ); contamination sources include $u$ aste disposal and leakage from petroleum refineries and industrial facilitie:. leakage from underground storage tanks. leakage from septic disposal systems, and percolation of fertilizers in irrigated areas Wells that yield contaminated water shown by county in figure $3 B$ may represent one or more wells in a particular area and generall! do not represent wells that are used for drinking water.

\section{Waste Disposal}

Hazardous wastes currently (1986) are being disposed at sitenear Kemmerer in Lincoln County, Casper, Evansville east (') Casper, and Sinclair in Carbon County (Wyoming Department of Environmental Quality, 1986b); these are some of the RCRA sites. Six of the RCRA sites are at oil refineries; the soils, water, or both at these sites have been contaminated by chemicals such as benzene. ethylbenzene, toluene, xylene, chloride. sulfate, and phenol. Another RCRA site is a phosphorus-processing plant south of $\mathrm{Kem}$ merer, where large dissolved-solids concentrations are being contributed to the ground water. A railroad tie-treatment facilit at Laramie (Albany County) is classified as both a CERCLA or Superfund site and a RCRA site (fig. 3A). The site at Laramie is contaminated by the toxic pollutants, creosote and pentachlorophenn'

The WDEQ has applied to the EPA for the classification of the Brookhurst subdivision, which is near the North Platte River east of Casper, as a CERCLA site (identified as "other" in fig. $3 A$ ). Several domestic wells completed in the alluvial aquifer near an oil refinery and an adjoining industrial area were discovered recent! to be contaminated with the suspected carcinogens. benzene and trichloroethylene. Although the extent and source of the contamina. tion have not been defined at this time (1986), the communut tia , been instructed by the WDEQ to obtain an alternative water supply

Fourteen hazardous-waste sites at Francis E. Warren Air Force Base in Laramie County. Wyoming were identified (September 1985) by the U.S. Department of Defense (DOD) as par of their Installation Restoration Program (1RP) as having potential for contamination (U.S. Department of Defense, 1986). The IRP. established in 1976, parallels the EPA Superfund program under the CERCLA of 1980 . The EPA presently ranks these sites under a hazardranking system and may include them in the NPL. After an initis! assessment completed under the program. 17 sites (fig. $3 A$ ) were recommended for a comprehensive survey to determine through environmental sampling and analysis whether problems exist (William Metz, U.S. Department of Defense. oral commun.. 1987). Remedial action at 1 of these 17 sites is underway.

Although no hazardous wastes are injected into underground wells in Wyoming, eight Class-I Underground Injection Control (UIC) wells (U.S. Environmental Protection Agency, 1984) are permitted by the WDEQ for industrial or municipal wastes (fig. $3 A$ ). Other injection wells (not shown in fig. $3 A$ ) in Wyoming include about 4,000 petroleum-related wells, 350 in-situ uranium-related wells, and 400 underground coal-gasification-related wells (Wyoming Department of Environmental Quality, 1987.

Sites identified as "other" in figure $3 A$ include 140 industrial landfills and 5 construction and demolition landfills. Each site represents one permit or one proposed permit; each permit may authorize one or more landfills. The number of county and municipal landfills is indicated by county in figure $3 C$. Ground-water quality is not monitored routinely at landfills in Wyoming; therefore. no ground-water-quality data are available for these sites.

Some septic-tank pumpers are contaminating ground water and surface water by improperly disposing of septic-tank wastes (Richards, 1986, p. A-3). The WDEQ reported three such viola- 
tions and several more suspected incidents that have occurred in the last few years (John Wagner. Wyoming Department of Environmental Qualıty. oral commun. 1986). The alluvial aquifer and possibly the High Plains and equivalent aquifers would be the most vulnerable to this type of contamination.

\section{Agriculture}

Irrigation can increase the concentration of dissolved solids in shallow aquifers. Salts accumulate in the soil after evapotranspiration has consumed the water. Some of the applied irrigation water transports these salts down to the water table. The alluvial aquifer along the Shoshone. Bighorn. and Big Sandy Rivers has been affected by this process (Wyoming Department of Environmenta] Quality, 1986a). Where soil has small porosity and slow drainage or where the water table locally is high, infiltration from irrigation can cause waterlogging. The fluctuation of the water table combined with evapotranspiration can result in the concentration of salts in the soil and in the ground water. causing an increase in dissolvedsolids concentrations. The Wyoming Department of Agriculture (WDA) began a monitoring program in 1986 to determine the possible degradation of ground-water quality resulting from irrigation.

Contamination by nitrate is fairly common in agricultural areas of Wyoming. Nitrates are leached from corrals and feedlots into the ground water. Nitrate fertilizers used on crops also may increase nitrate concentrations in ground water. Large nitrate concentrations have been detected in ground "water samples from wells in agricultural areas in Laramie, Goshen. Fremont. Washakie, Bighorn. and Park Counties (fig. $3 B$ ).

The WDA has monitored surface water for the presence of pesticides for several years. Although contamination of ground water by pesticides has not been well documented in Wyoming. extensive usage presents a potential problem.

\section{Mineral Extraction and Processing}

Large dissolved-solids concentrations in ground water have been associated with spoil material at coal mines and tailings-disposal sites at trona mines. Concentrations of dissolved solids in spoil water at the mine sites generally are larger than concentrations in water from nearby stock and domestic wells, but some of the spoil water is acceptable for use by livestock. Few people are affected by these large dissolved-solids concentrations because of the sparse population near the mines and the slow rate of ground-water movement from mine spoils.

The WDEQ lists 10 sites where seepage from uranium tailings ponds has escaped past the pumpback systems to increase concentrations of dissolved solids, sulfates, chlorides, and radionuclides in the structural basin aquifer (Michael Carnevale, Wyoming Department of Environmental Quality, written commun., 1986). Leachates from five uranium mines have extended beyond the recovery wells. Seepage from a tailings pond at a uranium processing mill in Fremont County is locally contaminating ground and surface water with cyanide, trace metals, and arsenic; the site is being investigated by the WDEQ.

Experimental underground coal-gasification bums have contaminated ground water at three facilities-in Campbell, Carbon, and Converse Counties. These areas have been contaminated locally by suspected carcinogens and constituents included on the EPA's priority list (U.S. Environmental Protection Agency, 1986c).

\section{Urbanization}

Sources of ground-water contamination within urbanized areas include leaking underground petroleum-product storage tanks and septic-tank leach fields. Leaking gasoline- and diesel-fuel storage tanks in or near various communities have contaminated local ground water. The WDEQ lists 55 such sites that have been or are being investigated pending additional ground-water-monitoring data (Tom Williams, Wyoming Department of Environmental Quality. written commun., 1987). Eight additional sites where diesel refueling, solvent spills. and illegal waste pits may have contributed hazardous toxic contaminants to the local ground water also are being investigated by WDEQ. This local contamination has occurred most commonly in aquifers underlying Wyoming's communities.

Wells serving several Wyoming communities have concentrations of nitrate exceeding the drinking-water standard. These wells are contaminated generally as the result of too many septic-tankdisposal systems in too small an area. Nitrate is the primary groundwater contaminant in Laramie County (fig. 3B).

\section{Potential for WATER-Quality Changes}

Changes in water quality may be expected in the future. These changes include increased nitrate concentrations in agricultural and urban areas, increased dissolved-solids concentrations in irrigated and mined areas, and contamination by petroleum products Pesticides in ground water have been documented in many agricultural areas outside Wyoming; however, studies is. Wyoming are just beginning.

Future contamination by nitrate in areas associated with the application of fertilizers and the use of septic tanks, such as in agricultural and urban areas, may be expected. The aquifers that most commonly occur in agricultural and urbanized areas are the alluvial aquifer and the High Plains and equivalent aquifers. Of these, the alluvial aquifer is very susceptible to nitrate contamination. The water table usually is very shallow, and the sand and gravel Iypical of this aquifer are very permeable. Nitrate concentrations $m$. $h$ : expected to remain relatively small in water from the strucLirdi basin aquifer primarily because the areas of occurrence are not significantly agricultural or urbanized. The structural basin aquifer also is much less susceptible to nitrate contamination because the depth to the water table generally is large, and the material between the land surface and the producing saturated zone is relatively impermeable.

Dissolved-solids concentrations generally may be expected to increase in irrigated and mined areas. Irrigation with ground water generally is practiced where either the alluvial aquifer or the High Plains and equivalent aquifers are present. Large dissolved-solids concentrations also are associated with mine spoils and may be expected to increase in mined areas. Mining generally occurs in the structural basin aquifer areas. Most water-quality changes in the structural basin aquifer are considered to be long term because of the slow movement of ground water in these units.

Contamination of ground water by petroleum products is fairly common in Wyoming, and contamination occurrences can be expected to increase as storage tanks and pipelines age, increased leakage occurs. Increased development of petroleum resources also increases the likelihood of accidental spills.

Incomplete data, along with complex geology, hinder any quantitative assessment of future contamination of ground-water supplies in Wyoming. Data are too sparse to permit spatial and vertical assessment of ground-water quality in many aquifers. The U.S. Geological Survey currently (1986) is studying the quality of water in and near several coal-spoil sites and the occurrence of selenium in surface water and ground water. These studies will improve the water-quality data base. Nevertheless, ground-water contamination can be expected to increase, based on the increasing number of sites where contamination or the potential for contamination, already has been identified.

The distribution of the industrial development and the relatively sparse urbanization in Wyoming currently (1986) decreases the potential for any statewide threat of contamination 
of the principal aquifers. However, continued regulation of activities that may contaminate ground water, as well as the development of a comprehensive statewide ground-water-quality network, would protect the future ground-water quality in Wyoming.

\section{GROUND-WATER-QUALITY MANAGEMENT}

The WDEQ-the principal State agency responsible for protecting the quality of ground water in Wyoming - shares and coordinates this responsibility with the EPA. The WDEQ was created in 1973 in response to the Federal Water Pollution Control Act of 1972.

Other State agencies also have regulatory responsibility for activities that potentially affect ground-water quality. The WDA regulates the use of pesticides and has monitored surface water for the presence of pesticides for several years. The Oil and Gas Commission regulates injection wells related to the production of oil and gas. The Wyoming State Engineer is charged by the Wyoming constitution with the administration of all waters within the State. Well permits are issued and water rights are administered by the Wyoming State Engineer's Office.

Three divisions in the WDEQ deal with ground-water quality - the Water Quality Division, the Land Quality Division, and the Solid Waste Management Program. The Water and Land Quality Divisions require monitoring of ground-water pollution through statutory requirements for commercial and research licenses. The Ground Water Operations Section of the Water Quality Division has the responsibility to protect both present and potential uses of ground water in Wyoming: the Section reviews construction plans and issues permits for surface facilities and underground injection control facilities. The Solid Waste Management Program regulates the operation of existing landfills and the design. location, and operation of new sites.

The Water Quality Division is also responsible for administering and enforcing the Wyoming Oil and Hazardous Substance Pollution Contingency Plan (Wyoming Department of Environmental Quality, 1986b). Although all spills must be reported to the Water Quality Division within 24 hours. the degree of Water Quality Division involvement in such situations is dependent upon the severity and complexity of the spill. Any necessary notification of downstream users and other agencies is conducted by the Water Quality Division. The State of Wyoming may recover not only State response expenses and penalties. but also costs for replacement of natural resources and wildlife. The Wyoming Game and Fish Department has a major role in these later efforts.

The EPA has primary responsibility for administering the RCRA and CERCLA sites. The EPA also enforces the national primary drinking-water regulations Although the State does not have primary responsibility, a State permit is required for any disposal of hazardous waste in Wyoming. During 1985, the Solid Waste
Management Program began requiring applications for hazardouswaste disposal.

\section{SELECTED REFERENCES}

Association of State and Interstate Water Pollution Control Administrators. 1985, Wyoming 1985 groundwater contamination, in America's clean water, The States' nonpoint assessment 1985-Appendix: Washington. D.C., Association of State and Interstate Pollution Control Administrators, $530 \mathrm{p}$.

Crist, M.A., 1974, Selenium in waters in and adjacent to Kendrick Project, Natrona County, Wyoming: U.S. Geological Survey Water-Supply Paper 2023, 39 p.

Durfor, C.N., and Becker, Edith, 1964, Public water supplies of the 100 largest cities in the United States, 1962: U.S. Geological Survey WaterSupply Paper 1812, 364 p.

Larson, L.R., 1984, Ground-water quality in Wyoming: U.S. Geological Survey Water-Resources Investigations Report 84-4034, 71 p.

Richards, Gwen. 1986, Health Department Director warns about groundwater contamination: Casper, Wyoming, Casper Star-Tribune. November 13, 1986, p. A-3.

U.S. Department of Defense, 1986, Status of the Department of Defense Installation Restoration Program-Information paper: Washington. D.C., U.S. Department of Defense, Office of the Assistant Secretary of Defense (Acquisition and Logistics), Environmental Policy Directorate, February, 35 p.

U.S. Environmental Protection Agency, 1984, Classification of injection wells (section 146.5 of subpart A of part 146. Underground injection control program: criteria and standards): U.S. Code of Federal Regulations, title 40. Part 146, July 1. 1984, p. 371-37.2.

1986a. Maximum contaminant levels (subpart B of part 141. $\mathrm{Na}$. tional interim primary drinking-water regulations): U.S. Code of Federal Regulations, Title 40 , parts 100 to 149 , revised as of July 1, 1986, p. 524-528.

1986b, Secondary maximum contaminant levels (section 143.3 of part 143. National secondary drinking-water regulations): U.S. Code of Federal Regulations. Title 40 . parts 100 to 149 , revised as of July 1, 1986, p. 587-590.

1986c, Amendment to national oil and hazardous substances contingency plan: national priorities list, final rule and proposed rule: Federal Register, v. 51, no. 111, June 10. 1986, p. 21053-21112

U.S. Geological Survey, 1985, National water summany, 1984-Hydrolugk events, selected water-quality trends, and ground-water resources: L'S Geological Survey Water-Supply Paper 2275, 467 p.

Wyoming Department of Administration and Fiscal Control. 1983. Wyoming data handbook: Cheyenne. Wyoming. 206 p.

Wyoming Department of Environmental Quality, 1986a, Statewide uater quality assessment 1986-Executive summary: Cheyenne. Wyoming. $26 \mathrm{p}$

1986b, Wyoming oil and hazardous substances pollution contingency plan: Cheyenne, Wyoming. 104 p. 1987, 1986 Annual report: Cheyenne, Wyoming: [in press.]

Wyoming Water Resources Research Institute, 1981, Occurrence and characteristics of groundwater in Wyoming: Laramie, 14 volumes.

Prepared by Karen L. Mora, L. R. Larson, and Samuel J. Rucker IV

FOR ADDITIONAL INFORMATION: District Chief, U.S. Geological Survey, P.O. Box 1125, Cheyenne, WY 82003 

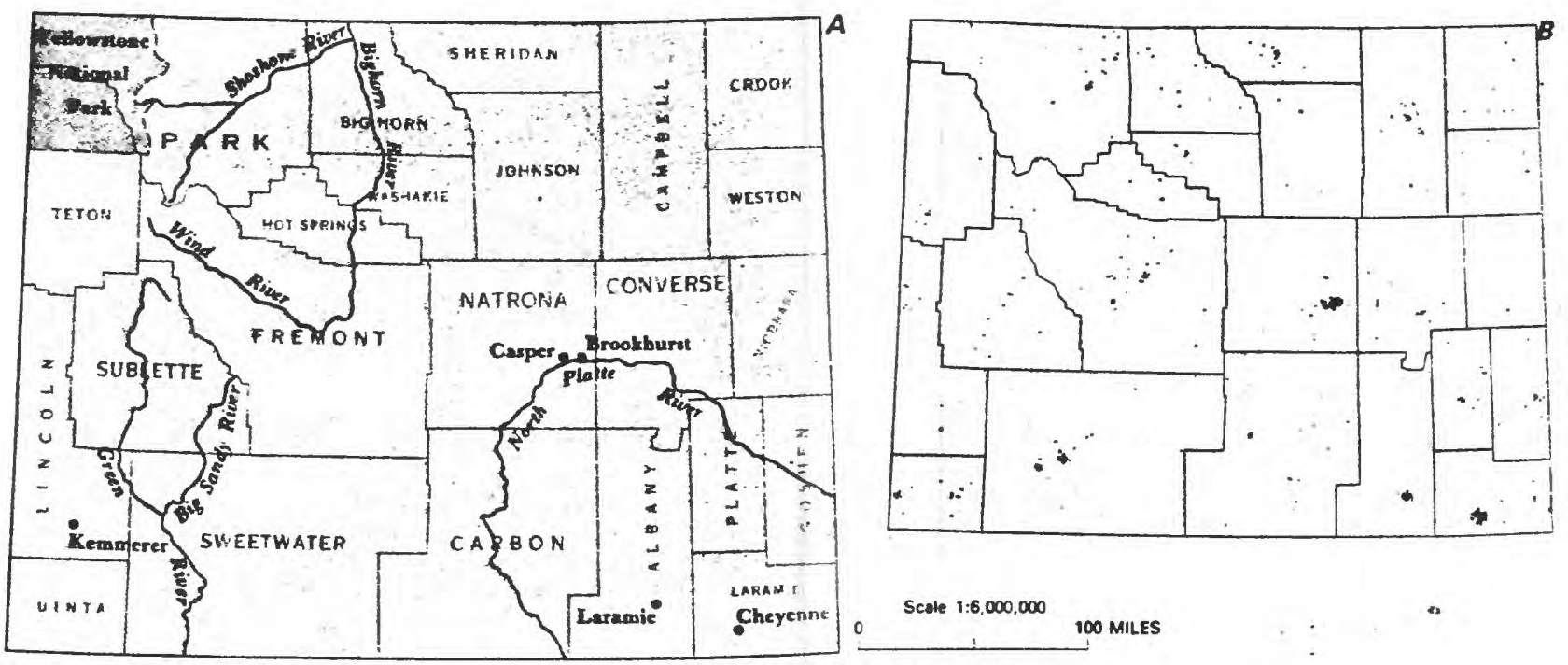

Figure 1. Selected geographic features and 1985 population distribution in Wyoming. A, Counties, selected citıes, and major draınages $B$ Fopute tion distribution 1985 each dot on the map represents 1.000 people. (Source B. Data from U.S. Bureau of the Census 1980 decennial census files, ad:usteC to the 1985 U $\leq$ Bureau of the Census data for county populations । 


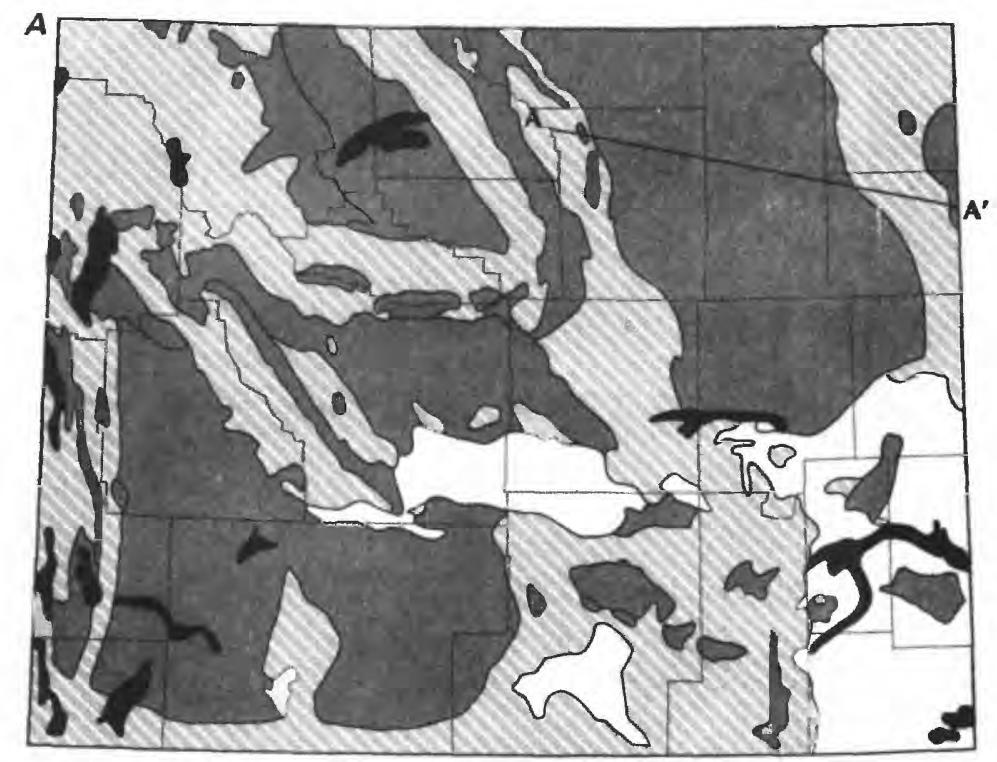

C WATER-QUALITY DATA - Maximum permissible contaminant
Parcantile - Percentage of analyses equal<smiles>OCC1CCCCC1(O)C(Br)(Br)c1ccccc1</smiles>

National drinklng-watar standards level (primary)

- - Maximum recommended contaminant level (secondary)

Reporting limit

Minimum reporting level with analytical method used

NUMBER OF ANALYSES
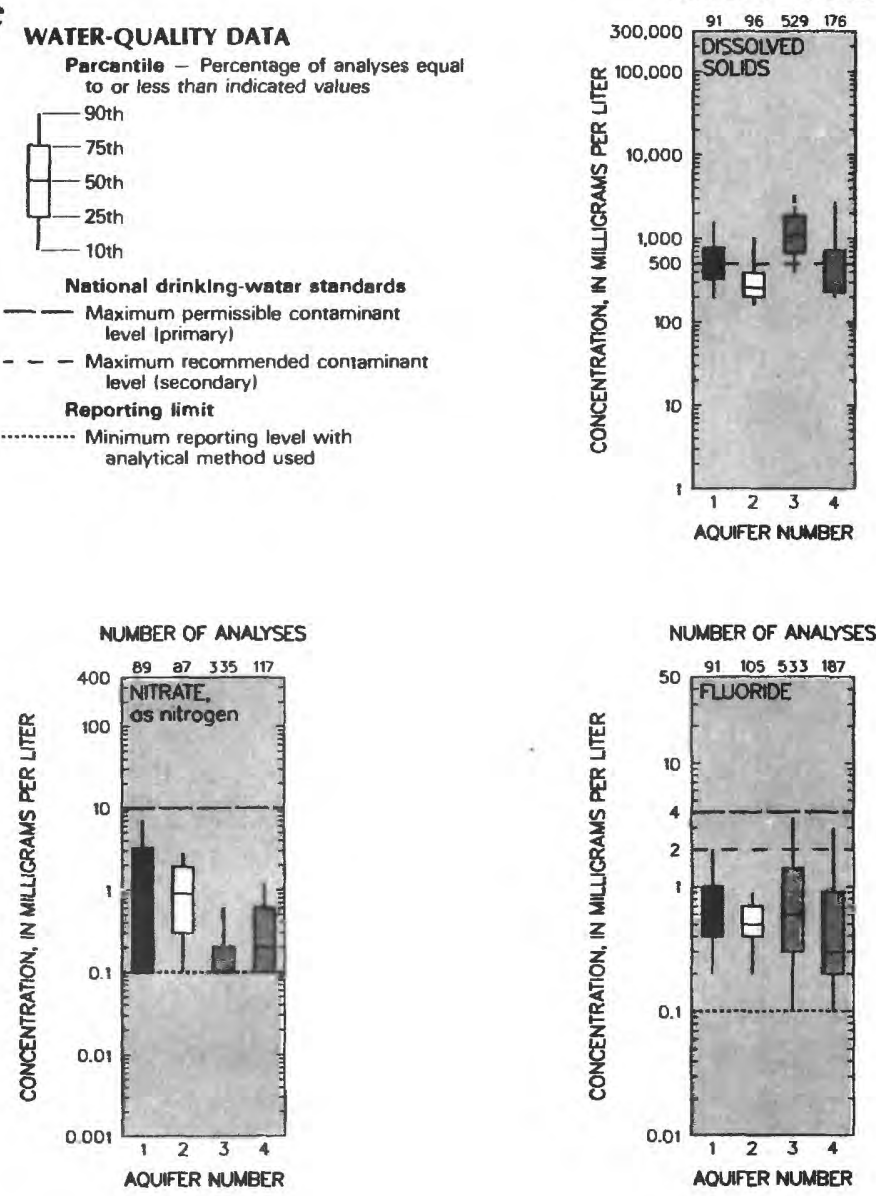

NUMBER OF ANALYSES

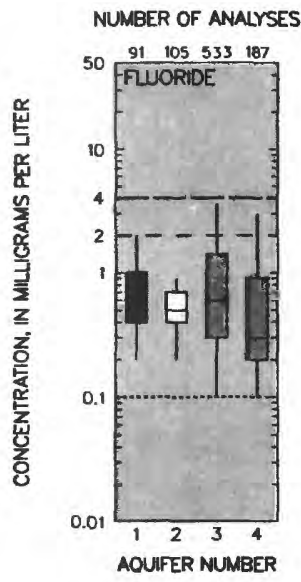

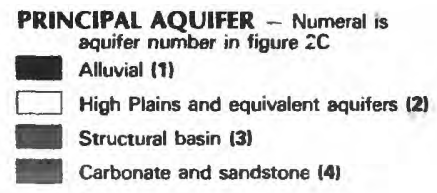

Not a principal aquifar

A-A' Trace of hydrogeologlc section

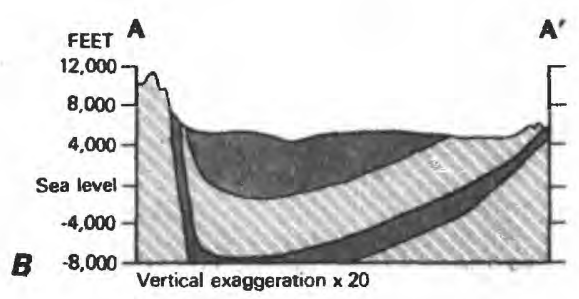

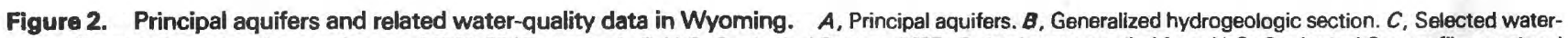
quality constituents and properties, as of 1960-85 (Sources: $A, B$, U.S. Geological Survey, 1985. C, Analyses compiled from U.S. Geological Survey files; national drinking-water standards from U.S. Environmental Protection Agency, $1986 \mathrm{a}, \mathrm{b}$. 


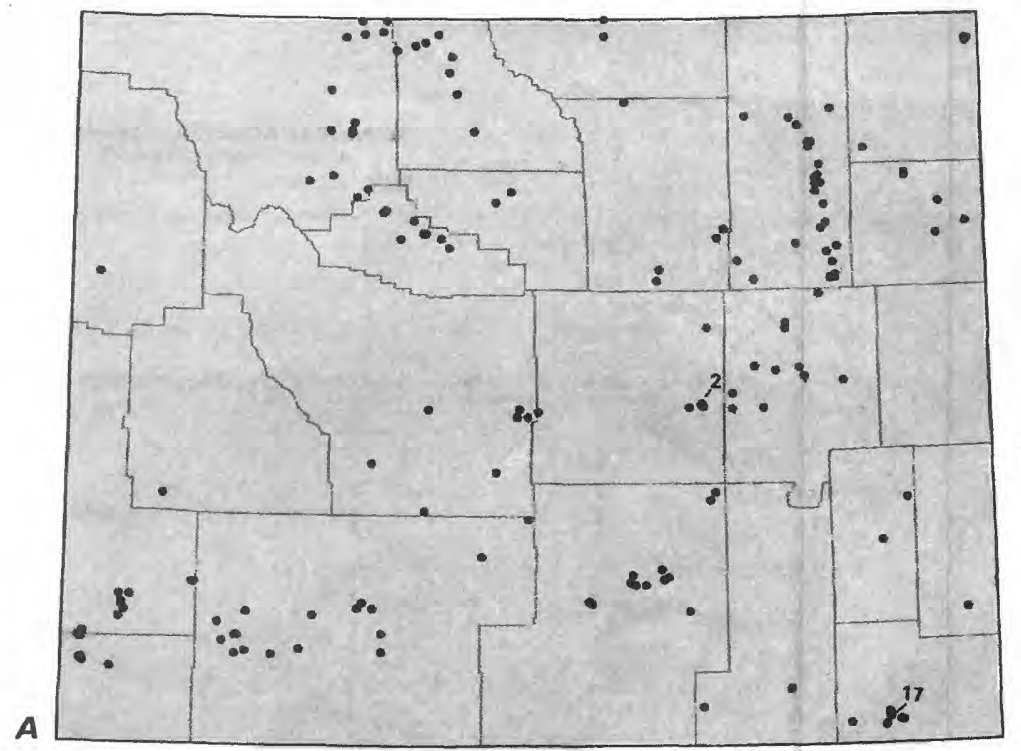

WASTE SITE - Darker symbol indicates site where contaminants were detected in ground water. Numeral indicates more than one site at same general location.

- Cercla (Superfund)

- ? RCRA

- 17. IRP

- Other

- Waste-disposal well IUnderground Injection Control, class II

\section{GROUND-WATER QUALITY}

Area of water-quelity concern Area of water-quelity concern F. fluoride; $\mathbf{A}$, radionuclides; S, seienium DZ Human-induced contaminataion

Wells thet yield contaminated water. by county

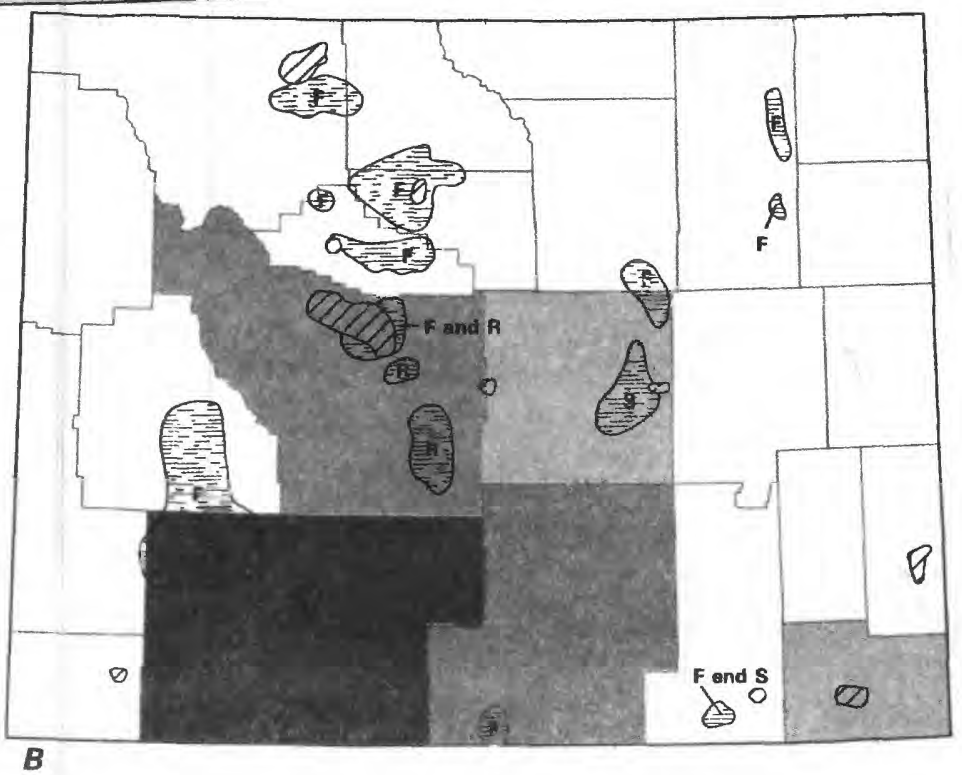

LANDFILL SITE

County or municipel landfills.

by county - Active and inactive

[D] $1-3$

14-10

11-20

Figure 3. Selected waste sites and ground-water-quality information in Wyoming. $\boldsymbol{A}$, Comprehensive Environmental Response, Compensation, and Liability Act (CERCLA) sites, as of 1986; Resource Conservation and Recovery Act (RCRA) sites, as of 1986; Department of Defense Installation Restoration Program (IRP) sites, as of 1985; and other selected waste sites, as of 1986. B. Areas of naturally impaired water quality, areas of human-induced contamination, and distribution of well sites that yield contaminated water, as of 1986. C. County and municipal landfills, as of 1986. (Sources: A, U.S. Environmental Protection Agency, 1986c; U.S. Department of Defense, 1986; Michael Carnevale, Wyoming Department of Environmental Quality, written commun., 1986. B, Association of State and Interstate Pollution Control Administrators, 1985; Michael Carnevale, Wyoming Department of Environmental Quality, written commun., 1986. C. Michael Carnevale, Wyoming Department of Environmental Quality, written commun., 1986.) 